\title{
Developing an Agro-Ecological Zoning Model for Tumbleweed (Salsola kali), as Energy Crop in Drylands of Argentina
}

\author{
Silvia FALASCA ${ }^{1 *}$, Sandra PITTA-ALVAREZ ${ }^{2}$, Ana ULBERICH $^{3}$ \\ ${ }^{1}$ CONICET Researcher, Climate and Water Institute, INTA, Argentina \\ ${ }^{2}$ CONICET Researcher, Department of Biodiversity and Experimental Biology, School of Exact and \\ Natural Sciences, University of Buenos Aires, Argentina \\ ${ }^{3}$ School of Humanities, CINEA, University of the Center of Province of Buenos Aires, Argentina
}

\begin{abstract}
Salsola kali is considered extremely valuable as an energy crop worldwide because it adapts easily to environments with strong abiotic stresses (hydric, saline and alkaline) and produces large amounts of biomass in drylands. This species is categorized as an important weed in Argentina. The aim of this work was to design an agro-ecological zoning model for tumbleweed in Argentina, employing a Geography Information System. Based on the bioclimatic requirements for the species and the climatic data for Argentina (1981-2010 period), an agro-climatic suitability map was drawn. This map was superimposed on the saline and alkaline soil maps delineated by the Food and Agriculture Organization for dry climates, generating the agro-ecological zoning on a scale of $1: 500000$. This zoning revealed very suitable and suitable cultivation areas on halomorphic soils. The potential growing areas extend from $\mathrm{N}$ of the Salta province (approximately $22^{\circ} \mathrm{S}$ ) to the Santa Cruz province $\left(50^{\circ} \mathrm{S}\right)$. The use of tumbleweed on halomorphic soils under semi-arid to arid conditions, for the dual purpose of forage use and source of lignocellulosic material for bioenergy, could improve agricultural productivity in these lands. Furthermore, it could also contribute to their environmental sustainability, since the species can be used to reclaim saline soils over the years. Based on international bibliography, the authors outlined an agro-ecological zoning model. This model may be applied to any part of the world, using the agro-ecological limits presented here.
\end{abstract}

Keywords - Salsola kali; bioclimatic requirements; agroclimatic suitability; drylands; agro-ecological zoning model; Argentina

\section{INTRODUCTION}

Within a low carbon society, there are three key components: the environment itself and the effects which are caused through carbon emissions (climate change, increased extreme and unpredictable conditions, biodiversity loss); policy making in different sectors (energy, transport, waste management and agriculture, etc.) with the ability to reduce the effects of carbon emissions on the environment; and low carbon generation with a change in thinking with behavior shifting towards renewable energy use, technology transfer to low carbon and green technology, lowercarbon emissions in transport and energy-saving practices [1].

According to reference [2] the hydrological systems change in response not only to natural variability of the Earth system, but also to human forces including land use, and land cover

* Corresponding author.

E-mail address: sfalasca@conicet.gov.ar 
changes, water supply, irrigation systems, infrastructure for electricity generation and global warming. Although Argentina is the eighth largest country in the world, $75 \%$ of its territory is comprised by arid, semiarid and dry-subhumid zones. According to [3], out of a total of 270 million ha, 60 million are affected by desertification processes. Approximately $30 \%$ of the population ( 9 million inhabitants) lives in these lands, and their per capita income is lower than the national average. Furthermore, the percentage of homes with unsatisfied basic needs doubles the national medium. This population lacks domestic fuels, such as natural gas or butane gas cylinders. As a result, they turn to the household use of woody vegetation for cooking and heating. Currently, there is no quantitative information concerning firewood and carbon consumption in Argentina and this is due mainly to the difficulties in measuring it. Family members that cut and collect firewood in situ are the same ones that use it.

It is estimated that in the late 19th to early 20th century, Argentina boasted near 100 million ha of woodlands. Indiscriminate logging contributed to deforestation, but this was augmented by a devastating phenomenon: clearance practices, carried out with heavy machinery, were implemented to add new lands and amplify the agricultural frontier, mainly for transgenic soybean production exported as bean and biodiesel to emergent Asian countries [4].

Extreme care must be taken to select the species to be cultivated in semi-arid and arid climates. This choice is determined by several factors, such as: temperature and precipitation, type of soil, water available for irrigation and purpose of cultivation.

One of the main causes of crop stress is the salinity of soil and water, since this reduces the hydric potential of the soil solution and decreases water availability. The high concentration of $\mathrm{Na}^{+}$and $\mathrm{Cl}^{-}$ions creates a nutritional imbalance that interferes with mineral nutrition and cellular metabolism.

Primary or natural salinization is the result of natural processes. However, secondary or induced salinity, which has been taking place in Argentina since European colonization, is the result of modifications in land management and irrigation practices. Due to mismanagement of irrigation practices, lands with salinity and alkalinity problems are predicted to be on the rise in the near future.

Halophytes have an enormous potential as energetic crops, since they can be grown in saline and alkaline soils. These species are very promising, particularly for reforestation purposes, ecological recovery of saline and alkaline areas in disuse, development and protection of coastal zones, production of lignocellulosic biomass for bioenergy and $\mathrm{CO}_{2}$ sequestration [5].

\subsection{Characteristics of Halophyte Salsola Kali}

Salsola kali L, (synonyms: S. tragus, S. kali var tragus or S. pestifer) is a xero-halophyte that belongs to the Chenopodiaceae family. It has several common names: Russian thistle, barrilla pinchosa, prickly saltwort, tumbleweed, glasswort [6]. The generic name Salsola means salty, while kali refers to ashes, in allusion to a sodium rich plant. This species colonizes dunes, constituting the first phase in the ecologic succession of dune formation; it is a shade-intolerant initial colonizer in primary and secondary succession. It colonizes barren desert areas that cannot support other flora [7], and invades many different disturbed plant communities [8].

Tumbleweed is native to Eurasia: Denmark, Estonia, Southern Finland, North and West of France, North Germany, NE Italy, NE Latvia, Lithuania, North Holland, South Norway, North Poland, Portugal, Russian Federation (Kaliningrad, Leningrad), North and South of Spain and South of Sweden [9].

$S$. kali is a weed found between $20^{\circ} \mathrm{N}$ and $50^{\circ} \mathrm{N}$ latitude, in the temperate zones of the Southern hemisphere. It is usually absent in vast areas that comprise tropical zones, Pacific islands and the Eastern coast of Africa [10]. It is categorized as an important weed in Argentina and Afghanistan, a main weed in Canada and Hungary and a common weed in Iran, Italy, Morocco, South Africa 
and the USA. It is also classified as a weed in Australia, Chile, China, Egypt, Greece, Hawaii, Indonesia, Iran, Japan, Lebanon, México, Norway, New Zealand, Pakistan, Poland, Turkey and the former USSR [10].

In Argentina, there are three types: Salsola kali var hirsute, Salsola kali var kali and Salsola kali var tragus (= Salsola tragus) [11].

Tumbleweed has an annual summer cycle and is highly polymorphic, with glabrous or hirsute stems that possess multiple ramifications and white or reddish streaks. It is highly branched and rounded in form, providing the adult plants with a globose appearance, growing from $0.3 \mathrm{~m}$ to $1 \mathrm{~m}$ in height and $0.3 \mathrm{~m}$ to $1.5 \mathrm{~m}$ in diameter. The awl-shaped, spiny-tipped leaves bear small, inconspicuous flowers in the leaf axils. The main root reaches depths of $1.5 \mathrm{~m}$ and the lateral roots extend up to $1.8 \mathrm{~m}$, allowing the capture of deep water in soil. A $0.5 \mathrm{~m}$ high plant can produce approximately 1500 to 2000 fire-resistant seeds, while taller plants can produce up to 100000 seeds [12]. These are dispersed by the wind when the plant is released from the soil, and they can travel a great distance. The seeds in the field remain viable for one or two years. Herbicides such as Dicamba and Glyphosate have been used successfully to eradicate it [13], although burning is the preferred method.

Some authors [14], [15] reported that it can be cultivated agriculturally to produce combustible biomass while [16] have suggested that the species can be a source for fuels in drylands, due to its low water consumption, its rapid germination in almost undisturbed soils, and the absence of pathogens and parasites. The Office of Arid Lands Studies in the University of Arizona analyzed the technical feasibility of processing $S$. kali as an alternative crop, particularly in trunks or pellets to be used as fuel [17]. The energetic content in a dry terrain field is (6500 to 6800) BTU/lb compared to lignite, which is (5580 to 7920) BTU/lb [16].

Tumbleweed is well adapted to environments with high abiotic stresses: hydric, saline and alkaline. In dry regimes, $S$. kali produces more biomass in mixtures than as a monoculture [18]. According to Duke [6] annual productivities are in the (6 to 10) ton $\mathrm{ha}^{-1}$ range for Salsola orientalis (with Eurotia spp and Kochia spp) in Kazakhstan (ex-USSR). This is in agreement with [14], in reference to natural stands of Salsola in Avra Valley, $32 \mathrm{~km}$ to the NE of Tucson. Wild pure stands produce (3 to 10) ton ha ${ }^{-1}$; while irrigated plots yield up to 15 ton $\mathrm{ha}^{-1}$ [6], [17].

Selected samples of natural pure stands indicate possible yields of 25 ton ha ${ }^{-1}$. Although in its original areas precipitations are in the (200 to 500) $\mathrm{mm}^{-{ }^{-1}}$ range, reference [15] estimated that with rainfalls of $200 \mathrm{~mm}$ yields of 8.92 ton $\mathrm{ha}^{-1}$ could be obtained, 17.84 ton ha ${ }^{-1}$ with $400 \mathrm{~mm}$ and 26.76 ton ha ${ }^{-1}$ with $600 \mathrm{~mm}$.

Young plants can be employed as forage. Chemical analyses have shown that it has $10 \%$ to $18 \%$ protein, $50 \%$ to $70 \%$ digestibility and $45 \%$ to $65 \%$ fiber [19]. When the plant begins to grow, its tissues are tender and turgid and it is an excellent vegetable, very similar to spinach, that can be eaten raw or cooked. Beyond that point, it is inedible. Tumbleweed is one of the plants that are burned to manufacture soap, and this use has been cited from Biblical times. Due to its high alkaline content, it has been employed in the manufacture of glass [20].

In addition, tumbleweed has been identified as a potential phyto-remediating plant, particularly for heavy metals, such as lead and cadmium [21], [22]. However, the extraction of metals is not efficient enough.

The objective of the present work was to design an agro-ecological zoning model to delimit the potential cultivation areas for $S$. kali on halomorphic soils under dry-subhumid, semiarid and arid climates, to produce solid biofuel. 


\section{Methods ANd Procedures}

\subsection{Study Area}

The Argentine Republic, which was the area under study, is located in southern South America and it extends from the subtropics to sub-polar regions in the south. To the North, it borders with Bolivia and Paraguay; to the South with Chile and the Atlantic Ocean; to the East with Brazil, Uruguay and the Atlantic Ocean and to the West with Chile (Fig. 1).

Because of its vast territory, Argentina presents a remarkable climatic diversity. The climatic characteristics of the different regions are influenced by various geographic factors. For example, the Argentine Republic is characterized by its great latitudinal development: $21^{\circ} 46^{\prime}$ in the North (Jujuy province) to $55^{\circ} 04^{\prime} \mathrm{S}$ in Cape San Pío (Tierra del Fuego province), in the South. The extreme eastern limit of the country is located at $53^{\circ} 38^{\prime} \mathrm{W}$, in the town of Bernardo de Irigoyen (Misiones province).

The limit between the sub-humid and semiarid zones is the $500 \mathrm{~mm}$ isohyet. To the West of this isohyet, the moisture gradient provided by rainfall from the South Atlantic anticyclone diminishes and the climate turns semi-arid.

The area located between (500 and 1000) $\mathrm{mm}_{\text {year }}{ }^{-1}$ presents a sub-humid climate, and when it exceeds $1000 \mathrm{~mm}$, the climate is humid.

\subsection{Climatic and Edaphic Requirements of Tumbleweed}

Salsola kali grows well in a wide variety of environments, particularly in semidesert locations, where high efficiency in water usage is required [10].

It is estimated that this xero-halophyte can be found in regions that range from the cold temperate desert to the steppe, and reaching the dry subtropical forest. Tumbleweed is found in regions with heights lower than $2700 \mathrm{~m}$, annual rainfalls of $260 \mathrm{~mm}$ to $970 \mathrm{~mm}$ and average annual temperatures from $9.2^{\circ} \mathrm{C}$ to $23.8^{\circ} \mathrm{C}[6]$.

Reference [23] reported that the species is rarely found in shadowed areas or in places that are usually humid during the growing season.

The seeds germinate in a wide range of temperatures $\left(0 / 15^{\circ} \mathrm{C}\right.$ to $\left.20 / 30{ }^{\circ} \mathrm{C}\right)$ with low osmotic potentials [12]. Furthermore, they can also germinate when night temperatures dip below $0{ }^{\circ} \mathrm{C}$ and diurnal ones are as low as $2{ }^{\circ} \mathrm{C}$ [24]. The thermal optimum lies in an ample range that spans from $7{ }^{\circ} \mathrm{C}$ to $35^{\circ} \mathrm{C}$ [16]. The maximum rate of germination has been reported at $17{ }^{\circ} \mathrm{C}$ and with $9.1 \%$ of soil moisture [25].

Successful germination requires loose soils and low humidity ( $8 \mathrm{~mm}$ of rain), and it usually occurs within a few hours. Most seeds are dormant during the winter and germinate in the succeeding spring [11].

According to Allen [18], S. kali reduces the biomass of competing herbaceous C3 under a high temperature regime $\left(21 / 31^{\circ} \mathrm{C}\right)$. In areas with limited water, the rapid growth of $S$. kali can deplete water resources, in detriment of other species, but it has no competitive advantage in conditions of high water availability.

To produce 1 gram of organic mass, plants with $\mathrm{C} 4$ metabolism consume usually half or onethird of the water needed by C3 plants. S. kali has a C4 photosynthetic metabolism, characterized by low water demand and high net photosynthetic rate, which allows for higher biomass production. Research has demonstrated that this species is one of the most water-efficient plants in the world, i.e.: it produces more biomass per unit of water than the majority of plants [6], [26], [27]. This efficiency is provided by the vast propagation of roots below the soil surface, which stimulate the extraction of underground water [26]. 
Reference [27] found that shoot production was higher when the soil was in the state of field capacity and lower when it was maintained at 0.1 of available water capacity. However, water usage efficiency was higher than 0.1 of the available water capacity, meaning that it only needed $98 \mathrm{~g}$ of water per gram of dry weight (DW) produced. Even under conditions of field capacity, tumbleweed uses only $181 \mathrm{~g}$ of water per gram of DW of shoots and roots.

Tumbleweed presents an indeterminate growth pattern, and flowering and seed formation continue until temperatures fall below $-3.9^{\circ} \mathrm{C}[26]$. Senescence occurs with the first frosts.

It is basically a plant that grows in well-drained alkaline soils, apparently due to reduced competition [7] in clay loam or sandy soils [29], [30]. It can be found in abundance in abandoned and fallow crop fields, and can tolerate alkaline pHs up to 8.2 [6]. Due to its tolerance to saline habitats, it can be found in the margins of marshes and swamps, but it does not tolerate saturated soils for long periods of time [31].

Some researchers [32] cultivated $S$. kali in a greenhouse and watered it with salinized nutritive solutions (electrical conductivity: from $1.3 \mathrm{dS} \mathrm{m}^{-1}$ to $33.9 \mathrm{dS} \mathrm{m}^{-1}$ ). The authors determined forage quality indices in early and full flowering, and they found that the quality, measured by total Nitrogen and fiber components, improved as salinity increased. The mineral content of the ashes also increased with saline stress in the growing periods. Nitrate and oxalate levels were not high enough to be toxic to ruminants. These authors confirmed that saline stress did not diminish the forage quality of tumbleweed.

\subsection{Agroclimatic and Agro-Ecological Zoning}

An adequate knowledge of agroclimatic conditions is crucial for the success of crops. Based on this knowledge, farmers can choose the appropriate moment to cultivate and also provide for plant requirements during the growing period.

Worldwide, arid zones are characterized by important precipitation deficits and large atmospheric demands that are estimated by the potential evapotranspiration. In these regions, the growing period depends on soil moisture. FAO [33] defines "arid zones" as those areas where the growing period extends from 1 to 179 days; and these include the regions climatically classified as arid, semiarid and dry-subhumid. Due to the lack of moisture at the end of the growing period, variations in yields can be very significant.

Initially, this research employed agro-climatology as the main tool. Thus, the requirements, limits and tolerance to bio-meteorological conditions for the species were identified, taking into account the climatic characteristics of the native areas and the successful areas of cultivation worldwide. Based on available bibliographic data, the bioclimatic requirements for $S$. kali were identified. Agro-climatic zoning was then carried out employing climatic data from all the metereological and agro-metereological stations in Argentina, corresponding to the period 1981-2010.

Using the available database, geographical limits were assigned according to the different variables that define suitability classes: very suitable, suitable and unsuitable for this species. The moisture regime was plotted based on the average annual rainfall, and it was classified as unsuitable when it was below $260 \mathrm{~mm}$; and suitable, when it surpassed these values [6].

The thermal regime was defined by the average annual temperature, which had to be above $9.2^{\circ} \mathrm{C}$. Areas lacking this thermal requisite were considered unsuitable [6].

All the collected information was normalized so as to integrate it into a Geographic Information System (GIS). This made it possible to apply spatial analysis tools that correlated the different levels of information. The maps were obtained using a series of previously interpolated bioclimatic variables. Afterwards, these were processed with the GIS tool of the Arc-GIS 9.3 program. Following the Ordinary Kriging interpolation method, the "Interpolate to Raster" tool, within the "3D Analyst" extension of the same program, was used for climatic interpolations. 
The agro-climatic suitability map was obtained by superimposing the average annual rainfall and average annual temperature maps.

Based on combinations of soil and climatic characteristics, zones can be delineated employing agro-ecological zoning. In this case, attention is focused on the climatic and edaphic requirements of crops and on the management systems under which the crops are grown. Each zone has a similar combination of restrictions and potential for land use, and this information is useful to deliver recommendations designed to improve the current land-use situation, either through increasing production or by limiting land degradation [33].

Employing the "Raster Calculator" tool of the "Spatial Analyst" extension of the same program, agro-climatic and agro-ecological suitability mapped variables were obtained from multivariable integration geo-processing. By superimposing the agro-climatic suitability map with the saline soil map and alkaline soil map of Argentinean Drylands, the agro-ecological zoning was obtained. This defines the potential growing areas for S. kali for biomass production on halomorphic soils.

\section{RESUlts}

\subsection{The Agro-Climatic Zoning}

Fig. 1 shows the political map of Argentina, with the names of the provinces. It is included to aid the readers living outside Argentina in the interpretation of the results.

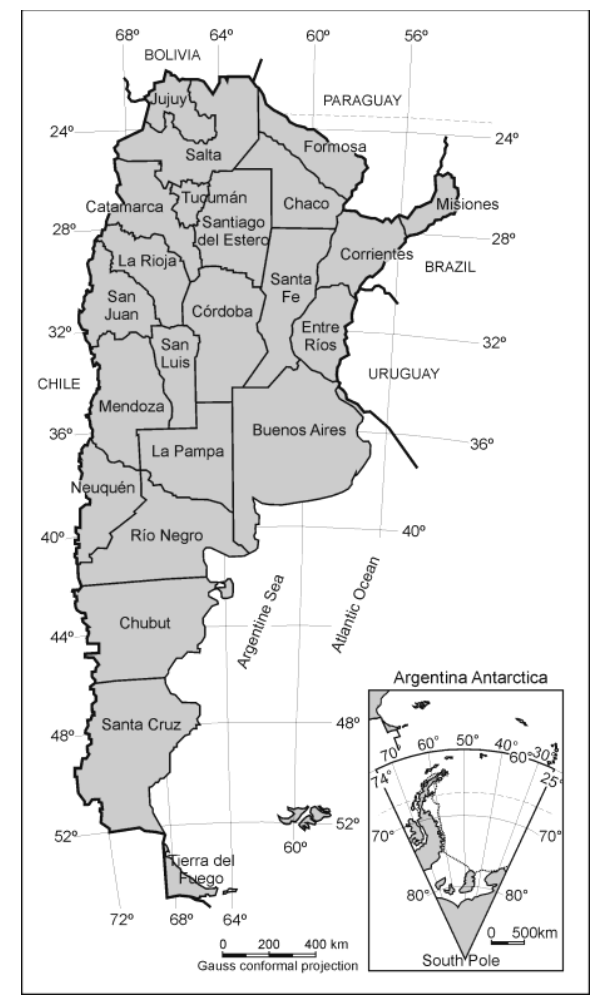

Fig. 1. Argentina's political map. 
Fig. 2 presents the thermal regions for tumbleweed. As can be observed in Fig. 2, a large part of Argentinian territory possesses thermal suitability for the development of tumbleweed cultivation, with the exception of the extreme NE of the country, West of San Juan, NE of Mendoza and West Patagonia down to Tierra del Fuego province. Argentina's climate is usually mild, with warm summers that last from late December through late March. Winters are also mild and last from late June to September. The highest temperatures are registered in the North and the lowest in the South. Mean annual temperature in the North is $24{ }^{\circ} \mathrm{C}$ and $0{ }^{\circ} \mathrm{C}$ in the South.

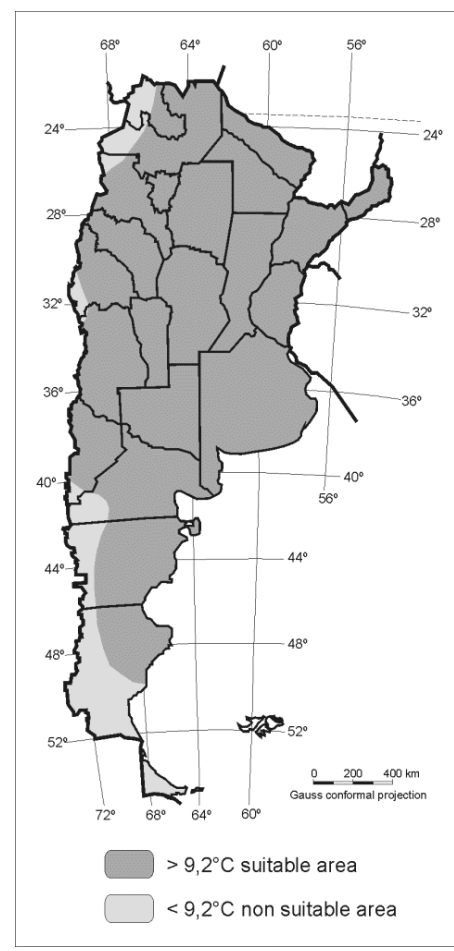

Fig. 2. Thermal regions: Average annual temperature $>9.5^{\circ} \mathrm{C}$.

In Fig. 3 the moisture regions can be observed. The very suitable areas comprise 2 sub-regions: the eastern, which covers all the east sector and North of the country, and the western, which covers the area corresponding to the mountainous region, from Mendoza to the South and contiguous areas. There are suitable areas that border the two sub-regions mentioned above; and these cover the East and South of Santa Cruz, areas in the vicinity of the Patagonian-Fuegian Forest and the eastern humid and sub-humid regions. These intersect in the center of Mendoza province.

The Andes Mountains represent an orographic barrier both to the main Pacific semi-permanent anticyclone flow from the West and to the Atlantic semi-permanent anticyclone flow from the East. Regional precipitation is determined principally by the topographic characteristics and the atmospheric conditions. North of the Colorado River, rainfall diminishes from east to west. The rainfall distribution in the course of the year has a first maximum during autumn. In addition, there is a prevailing circulation derived from the semi-permanent Atlantic anticyclone and air masses having their origin in tropical areas. 


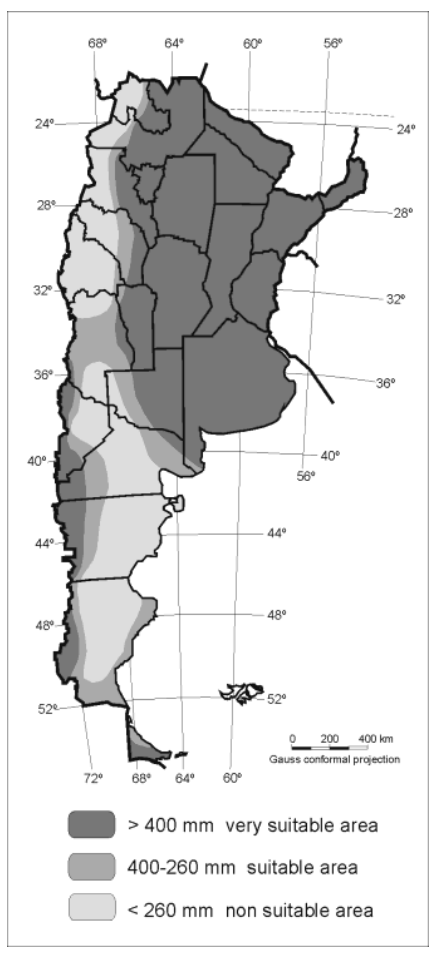

Fig. 3. Moisture regions: annual rainfalls.

The eastern part of the South Pacific anticyclone influences the climate of most of South America's west coast, causing stable, subsiding air conditions that yield minimal precipitation. Windward of the Andes, southern $35^{\circ} \mathrm{S}$, the region shows a winter precipitation regime. As the westerly winds rise over the Andes, most of their moisture is released in orographic precipitation (Patagonian-Fuegian Andes with $>1000 \mathrm{~mm}$ ), while on the lee side develops the vast desert and semi-desert region of Patagonia. The east coast of Patagonia receives greater amounts of precipitation from the winds emanating from the South Atlantic, and the humidifying action of the warm air currents forms a belt of low pressure.

Fig. 4 shows the agro-climatic suitability in Argentina for the cultivation of tumbleweed, and the very suitable, suitable and unsuitable areas are clearly delineated. This map represents potential growing areas from an agro-climatic point of view. Very suitable areas cover the Eastern humid and sub-humid sector and part of the SE of the Mendoza province and West Neuquén. Suitable areas can be found in a peripheral zone located west of the very suitable area, from Jujuy to East Río Negro, including a large part of the Mendoza province and two bands: one covering part of Neuquén, Río Negro, Chubut, and the other East of Santa Cruz. 


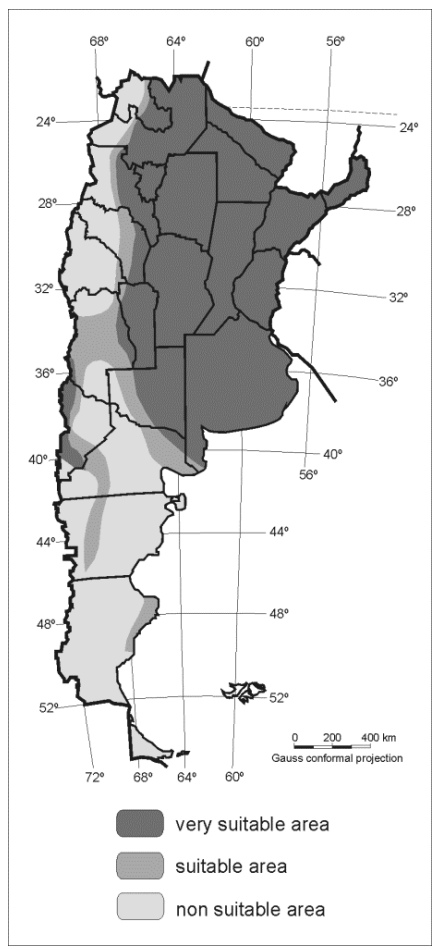

Fig. 4. Agroclimatic suitability.

\subsection{The Agro-Ecological Zoning}

Sodium cations are prevalent in saline soils, and these have electrical conductivity (EC) values greater than $4 \mathrm{dS} \mathrm{m}^{-1}$. Usually, soluble chloride and sulfate are the main anions. Salinity of soils in Argentinian Drylands was plotted based on the salinity classification [34], and the potential sites for $S$. kali implantation identified were the "moderately saline phase", with soil electrical conductivity ranging from $8 \mathrm{dS} \mathrm{m}$ m $^{-1}$ to $16 \mathrm{dS} \mathrm{m}^{-1}$ and the "strongly saline phase", with values surpassing this range. This can be appreciated in Fig. 5.

Sodic soils are characterized by their high $\mathrm{pH}$ levels with a high Exchangeable Sodium Percentage $(>15 \%)$. Furthermore, they have elevated concentrations of free carbonate and bicarbonate and excess of sodium on the exchangeable site of clay particles. They are also deficient in nitrogen, phosphorus and zinc. Alkalinity of soils in Argentinean Drylands was plotted based on the FAO's alkalinity classification [34], which considers moderately alkaline soils (Exchangeable Sodium Percentage ranging from $15 \%$ to $40 \%$ ) and strongly alkaline soils (in excess of $40 \%$ ). These locations were marked as possible sites for tumbleweed cultivation. As mentioned above, this species can inhabit areas with a wide range of $\mathrm{pH}$ values, ranging from 6.5 to 8.2 (neutral to strongly alkaline). This is shown in Fig. 6. By superimposing the agro-climatic suitability map (Fig. 4) over the maps pertaining to the salinity of soils (Fig. 5) and the alkalinity of soils (Fig. 6) for Argentinean Drylands, delineated by [34], the agro-ecological zoning for $S$. kali was obtained (Fig. 7).

The ensuing map, on a scale of $1: 500000$ delineates the very suitable, suitable and unsuitable areas and offers an overall idea of the expansion potential for this crop in Argentina. This preliminary zoning will allow a detailed mapping in the future when production is launched. 
In the agro-ecological suitability map (Fig. 7), it can be observed that the very suitable areas cover part of the provinces of Salta, Formosa, Chaco, Santiago del Estero, Santa Fe, Córdoba, Río Negro, Buenos Aires, Catamarca and San Luis. Suitable areas comprise part of the provinces of Catamarca, San Juan, Mendoza, Río Negro, Buenos Aires, Chubut and Santa Cruz.

\section{DiscuSSION}

\subsection{The Agro-Climatic Zoning}

In the agro-climatic suitability map (Fig. 4), very suitable, suitable and unsuitable areas were delineated from an agro-climatic point of view. Very suitable areas can be found in the eastern humid-subhumid and part of the southwest of the Mendoza province and west of Neuquén. Suitable areas cover part of the provinces of Jujuy, Salta, Catamarca, La Rioja, San Juan, Mendoza, Neuquén, La Pampa, Buenos Aires, Río Negro, Chubut and Santa Cruz.

These results are in agreement with reference [9], who described tumbleweed as a common species in the semi-arid central region of Argentina. These authors also stated that, in the province of Salta and in the Northeast of Argentina, tumbleweed is one of the most damaging weeds for summer crops, fruit, fruit-tree crops, perennial pastures and natural forage fields. In particular, it is an extremely aggressive weed for traditional crops in Valle de Lerma (province of Salta), displaying a uniformity and density that resemble a pure culture of this weed.

According to the same authors [11], in the semiarid diagonal, this species acts as a weed in anthropic modified environments due to cultivation and soil removal, such as road verges, railway embankments, edge of ditches and slopes of dams, wired areas, natural pastures and cultivation parcels with alfalfa, olives, tobacco, corn and stone fruit trees. The semiarid diagonal coincides with the area delineated as suitable in the agro-climatic suitability map (Fig. 4).

In the area delineated as very suitable, which is the South of the Buenos Aires province, farmers allow the weed to grow up to $0.30 \mathrm{~m}$ from the topsoil in order to control wind erosion, and later use it as forage. Although management adjustments must be introduced, the young weed which is tender and without spines, could be used in some cases under high grazing intensity or assembling bales with the green and young plants.

Its use as forage is being evaluated in the province of La Pampa. Currently, there are assays being carried out related to meat production. However, care must be taken when tumbleweed is used for forage because, in early stages, the species is palatable and has good forage quality, but it can contain an excess of nitrates and oxalates that can be toxic and laxative when it is the sole constituent of the diet [35]. Since these substances probably accumulate in the young parts of the plant, tumbleweed must be mixed with other forages and it can only constitute a third or half the ration. If hay cutting is delayed and the spines harden, it must be sprayed with water 10 or 12 hours prior to its use so that the spines soften and the animal can eat it. 


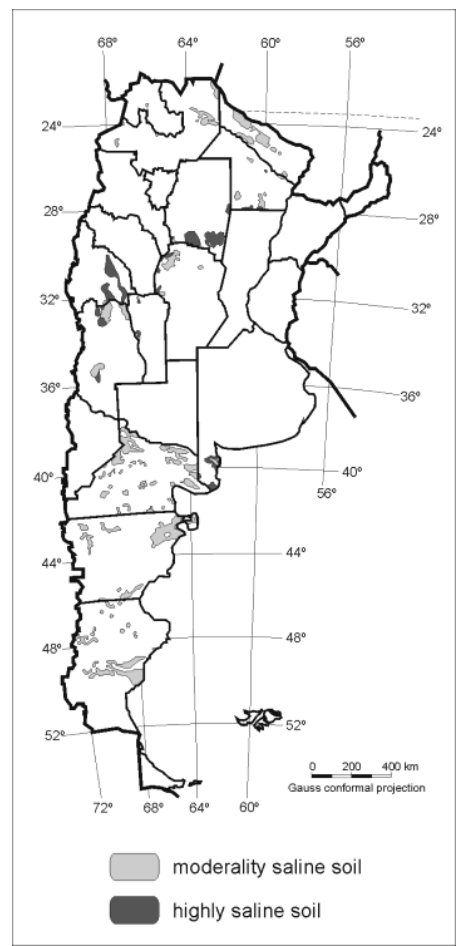

Fig. 5. Salinity of soils in Argentinean Drylands [34] in dry regions (arid, semiarid and dry-subhumid climates) [33]. Moderately saline phase EC: (4 to 8$) \mathrm{dS} \mathrm{m}^{-1}$ and Strongly saline phase EC: $>16 \mathrm{dS} \mathrm{m}^{-1}$.

The Argentine provinces classified as agro-climatically suitable to cultivate tumbleweed are largely the same as the areas where the species has been detected in our country by the Biodiversity Information System [36]. These are the provinces of Buenos Aires, Chubut, La Pampa, Mendoza, Neuquén, Río Negro, San Juan and Santa Cruz. This reference [36] does not mention the Northeast Argentine provinces (Salta, Jujuy, La Rioja and Catamarca) because according to [11], the species was recently detected in these regions.

\subsection{The Agro-Ecological Zoning}

In the agro-ecological suitability map (Fig. 7), it can be observed that the potential growing areas extend from $\mathrm{N}$ of the Salta province (approximately $22^{\circ} \mathrm{S}$ ) to the Santa Cruz province $\left(50^{\circ}\right.$ $\mathrm{S})$. This is in agreement with [10], who described its distribution as a weed from $20^{\circ} \mathrm{L}$ to $50^{\circ} \mathrm{L}$. Cultivation has to be explored in the areas classified as very suitable and suitable but that, due to halomorphic constraints, do not overlap with the ones used for the production of traditional food.

Although biomass production of tumbleweed implies the extensive use of land, the land proposed for its cultivation has no agricultural suitability. Nevertheless, the crop has to be well managed due to its aggressive and competitive behavior. In Argentina, the species fructifies in autumn and seed dispersal occurs mainly through the wind, particularly towards the end of the cycle when the plant is released from its radicle system. Therefore, harvest must be carried out before fructification to avoid intensifying the use of herbicides in agricultural lands or implanted pastures that could be in the vicinity. 


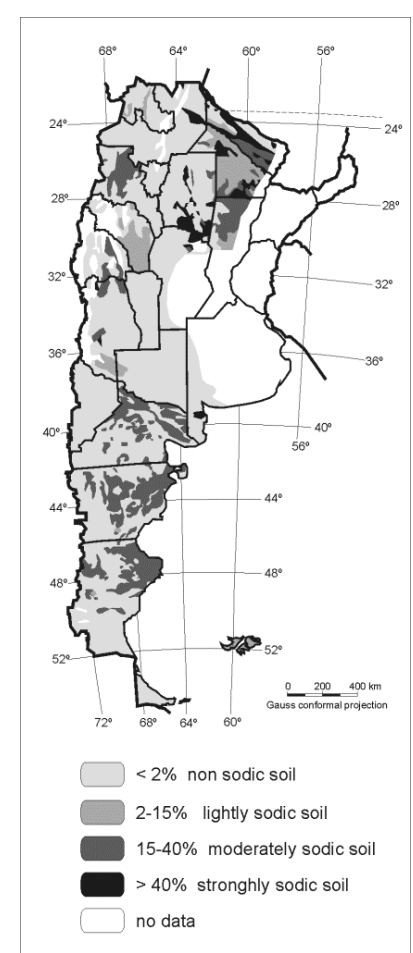

Fig. 6. Alkalinity of soils in Argentinean Drylands [34] based on the Exchangeable Sodium percentage (\%) in dry regions (arid, semiarid and dry-subhumid climates) [33].

Salsola kali is a plant that can grow in marginal areas without irrigation or fertilizers. Consequently, its use as an energy crop can be extremely beneficial to regional economies that depend on semiarid or arid lands. Many of them have been negatively affected by inter-annual variations in precipitations. Furthermore, tumbleweed can aid in the ecological recovery of saline and/or alkaline soils.

The biomass provided by tumbleweed can be used for different energetic purposes, such as biogas production, thermal and electric energy, in rural and semi-rural regions of Argentina, thus reducing the need to cut endemic bushes for firewood.

In Argentina, unlike other countries, the production of biomass to produce electricity and inject it into the energy network by way of electric cogeneration plants that also use the energetic residues of other industrial processes, is unusual. Therefore, the most interesting application using tumbleweed biomass would be the generation of electricity in isolated rural areas, thus introducing new technology and improving the life quality of rural dwellers. 


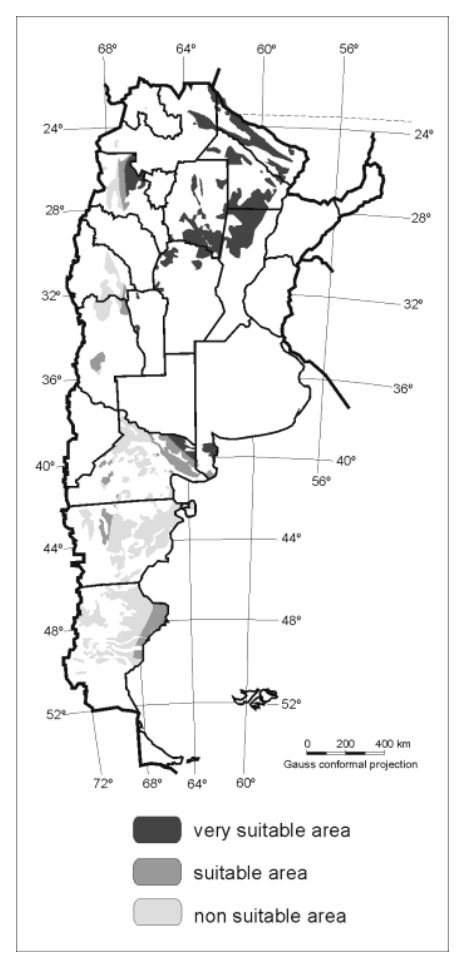

Fig. 7. Agro-ecological zoning for tumbleweed.

The information presented in the agro-ecological suitability map, on a scale of $1: 500000$ is important for national planning purposes because it offers an overall idea of the expansion potential for this crop in Argentina. However, this macro-zoning should be considered as a reference for the production stage. When production projects are developed, either at the municipal or provincial level, larger scale analyses are recommended.

If lands with salinity and alkalinity problems were to increase in the near future, due to irrigation mismanagement, the use of this species on halomorphic soils for the dual purpose of forage use and source of lignocellulosic material for bioenergy under semiarid to arid climatic conditions would represent a difficult but necessary step to guarantee both agricultural productivity and environmental sustainability in these regions. Furthermore, its use is recommendable to reclaim saline soils because this plant can diminish the salt content of soil over the years.

Since the plant is an aggressive and competitive weed [37], it has to be managed carefully. Harvest must take place before fructification to avoid the dispersal of seeds, since this could bring about the intensification in the use of herbicides in the vicinity of areas with traditional agriculture or implanted pastures. The seeds can remain viable in the soil for several years, even if they are buried deeply. To avoid weed infestation, its dispersal must be strictly controlled with tillage machinery. If the plants are a few centimeters high, they must be reaped with mowers before fructification takes place. Later, they must be cordoned off and burned, or directly burned in autumn before they start breaking. When there are few plants, they must be pulled out, burned or controlled chemically with systemic herbicides such as 2,4-D, MCPA or 2,4-DB. 


\section{CONCLUSION}

The authors delineated an agro-ecological zoning model for tumbleweed. This model may be applied to any part of the world, using the agro-ecological limits presented in this work.

The suitable areas were collated with international bibliographic data and the Biodiversity Information System for Argentina. Potential growing areas extend from $\mathrm{N}$ of the province of Salta (approximately $\left.22^{\circ} \mathrm{S}\right)$ to the Santa Cruz province $\left(50^{\circ} \mathrm{S}\right)$. The very suitable and suitable areas derived from the agro-ecological zoning do not overlap with lands destined for traditional crops, due to salinity and alkalinity problems (moderate to strong alkalinity and/or moderate to strong salinity) and it is in these regions where cultivation should be encouraged.

\section{ADDITIONAL INFORMATION}

We want to highlight that: 1) The paper is original and has not been published or sent to another Journal for publication; 2) The author and co-authors declare that they have no competing interests, financial or otherwise; 3) Authors declare acceptance of the copyright conditions specified therein with the submission of this paper.

\section{ACKNOWLEDGEMENT}

This research was supported by the National Council of Scientific and Technical Research (CONICET) of Argentina.

\section{REFERENCES}

[1] Martins J. A., Brand V. S., Capucim M. N., Machado C. B., Allasia Piccilli D. G., Martins L. D. The Impact of Rainfall and Land Cover Changes on the Flow of a Medium-sized River in the South of Brazil. Energy Procedia 2016:95:272-278. doi:10.1016/j.egypro.2016.09.068

[2] Kalnins S. N., Blumberga D., Gusca J. Combined methodology to evaluate transition to low carbon society. Energy Procedia 2015:72:11-18. doi:10.1016/j.egypro.2015.06.003

[3] Secretaría de Ambiente y Desarrollo Sustentable. Secretariat of Environment and Sustainable Development of Argentina. Desertification Manual of Argentina, 2005.

[4] Falasca S. Energy crops for biofuels: the Argentinean agroclimatic suitability. Madrid: Editorial Academica Espanola, 2012.

[5] Falasca S., Miranda C., Waldman C. Halophytes: feedstocks for bioenergy in Argentina. Advances in Energy Research. Book 17. New York: Nova Science Publishers, 2014.

[6] Duke J. A. Salsola kali L. Handbook of energy crops. 1983. [Accessed 13.06.2015]. Available: https://www.hort.purdue.edu/newcrop/duke_energy/Salsola_kali.html.

[7] Young J. A. Tumbleweed. Scientific American 1991:264:82-87. doi:10.1038/scientificamerican0391-82

[8] Beatley J. C. Russian-thistle (Salsola) species in western United States. Journal of Range Management 1973:26(3):225-226. doi:10.2307/3896700

[9] GRIN. The Germplasm Resources Information Network. Grin Taxonomy. United States Department of Agriculture, Agricultural Research Service, 2000.

[10] Holm L., Doll J., Holm E., Pancho J., Herberger J. Salsola kali L. World weeds: natural histories and distribution. New York: John Wiley, 1977.

[11] Zuloaga F. O, Morrone. Catalogue of Vascular Plants of the Argentine Republic. Pteridophyta, Gymnospermae and Angiospermae (Monocotyledoneae). Missouri Botanical Garden, St. Louis. Monographs in Systematic Botany 1996:60:1-332.

[12] Young J. A., Evans R. A. Germination and establishment of Salsola in relation to seedbed environment. Temperature, after ripening, and moisture relations of Salsola seeds as determined by laboratory studies. Agronomy Journal 1972:64:214-224.

[13] California Noxious Weed Management Projects Inventory. Natural Resource Projects Inventory, Information Center for the Environment, University of California, 1997. 
[14] Foster K. E., Karpiscak M. M., Taylor J. G., Wright N. G. Guayule, Jojoba, Buffalo Gourd and Russian Thistle: Plant Characteristics, Products and Commercialization Potential. Desert Plants 1983:5(3):112-126.

[15] Meinel M. P, Meinel A., Karspicak M. Potential uses of Russian Thistle and other weeds as an energy resources. Arid lands Newletter. Office of Arid Lands Studies. Tucson: University of Arizona, 1980.

[16] Foster K. E., Karpiscak M. M. Arid lands plants for fuel. Biomass 1983:3(4):269-285. doi:10.1016/0144-4565(83)90018-5

[17] Karpiscak M. M., Rawles R. L., Foster K. E., Meinel A. B., Meinel M. P. The feasibility of using Russian thistle (Salsola kali L.) for bioconversion. A quarterly report of work performed under U.S. Department of Energy Grant No. DE -FG03-79SF10550. University of Arizona, 1980.

[18] Allen E. B. Germination and competition of Salsola kali with native $\mathrm{C}_{3}$ and $\mathrm{C}_{4}$ species under three temperature regimes. Bulletin of the Torrey Botanical Club 1982:109:39-46. doi:10.2307/2484466

[19] Hageman J., Fowler J., Suzukida M., Salas V, Lecaptain R. J. Analysis of Russian Thistle (Salsola Species) Selections for factors affecting forage nutritional value. Journal of Range Management 1988:41(2):155-158.

[20] Watt J. M., Breyer-Brandwijk M. G. The medicinal and poisonous plants of southern and eastern Africa. 2nd ed. Edinburgh and London: Livingstone, 1962.

[21] De la Rosa G., Peralta-Videa J. R., Montes M., Parsons J. G., Cano-Aguilera I., Gardea-Torresdey J. L. Cadmium uptake and translocation in tumbleweed (Salsola kali), a potential Cd-hyper-accumulator desert plant species: ICP/OES and XAS studies. Chemosphere 2004:55:1159-1168. doi:10.1016/j.chemosphere.2004.01.028

[22] Ben Rejeb K., Ghnaya T., Zaier H., Benzarti M., Baioui R., Ghabriche R., Wali M., Lutts S., Abdelly C. Evaluation of the $\mathrm{Cd} 2+$ phytoextraction potential in the xerohalophyte Salsola kali L. and the impact of EDTA on this process. Ecological Engineering 2013:60:309-315. doi:10.1016/j.ecoleng.2013.07.026

[23] Crompton C. W., Bassett I. J. The biology of Canadian weeds. Salsola pestifer A. Nels. Canadian Journal of Plant Science 1985:65:379-388. doi:10.4141/cjps75-072

[24] Evans R. A., Young J. A. Germination and establishment of Salsola in relation to seedbed environment. II. Seed distribution germination and seedling growth of Salsola and microenvironment monitoring of the seedbed. Agronomy Journal 1972:64:219-224. doi:10.2134/agronj1972.00021962006400020027x

[25] Wallace A., Rhods V. A, Frobich E. F. Germination behaviour of Salsola as influenced by temperature, moisture, depth of planting, and gamma irradiation. Agronomy Journal 1968:60:76-78. doi:10.2134/agronj1968.00021962006000010024x

[26] Young F., Veseth R., Thill D., Schillinger W., Ball D. Managing Russian thistle under conservation tillage in cropfallow rotations. Pacific Northwest Extension Publication 492. University of Idaho, Oregon State University and Washington State University, 1995.

[27] Baker H. G. Proceedings of the Western Society of Weed Science 1974:27:73.

[28] Dwyer D. D., Wolde-Yohannis K. Germination, emergence, water use and production of Russian thistle (Salsola kali L.). Agronomy Journal 1971:64(1):52-55. doi:10.2134/agronj1972.00021962006400010017x

[29] Scoggan H. J. Flora of Manitoba. Bull. National Museum of Canada, 1957.

[30] Moss E. H. Flora of Alberta. 2nd ed. Toronto: University of Toronto Press, 1983.

[31] Weeds B. C. Russian thistle. 1999.

[32] Fowler J. L., Hageman J. H., Moore K. J., Suzulsida M., Assadian H., Valenzuela M. Salinity effects on forage quality of Russian thistle. Journal of Range Management 1992:45:559-563. doi:10.2307/4002572

[33] FAO. Agro-Ecological Zoning Guidelines. FAO Soils Bulletin 76. Rome: Food and Agriculture Organization of the United Nations, 1996.

[34] Food and Agriculture Organization of the United Nations. Principal Orders, Suborders and Great Soil Groups present in the dry regions of Argentina (Soil Taxonomy, 1979). 2008. [Online] [Accessed 20.12.2014]. Available: http://www.fao.org/ag/agl/agll/lada/arg/Archivos/04\%20-\%20Recursos/suelo.htm

[35] Kingsbury JM. Poisonous plants of the United States and Canada. Science 1964:145:1425-1426. doi:10.1126/science.145.3639.1425-a

[36] Biodiversity Information System of Argentina. SIB: Salsola kali [Online] [Accessed 21.09.2015] Available: http://www.sib.gov.ar/ficha/PLANTAE*salsola*kali.

[37] Nackley L. L., Quinn L. D., Matlaga D. P., Barney J. N. Good intentions vs good ideas: evaluating bioenergy projects that utilize invasive plant feedstocks. Bioenergy and Biological Invasions: Ecological, Agronomic and Policy Perspectives on Minimizing Risk. Invasive Series 5. UK: CABI, 2015. doi:10.1079/9781780643304.0134 


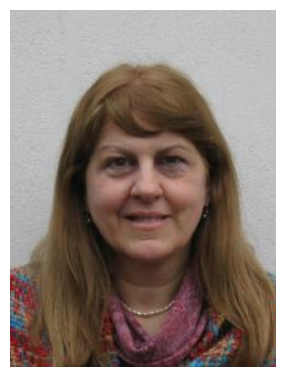

Silvia L. Falasca. Agronomist and Agro-climatology specialist. Professor of Climatology since 1982 of the School of Agronomy of Buenos Aires University, and Geography Department and Environmental Management of the School of Humanities, National University of the Centre of the province of Buenos Aires. Research Scientist of the National Council of Scientific and Technological Research (CONICET) of Argentina since 1989. Professor of Nontraditional crops for bioenergy in the Master of Science: Renewable Energies. National Technological University. Director of the Program on the Environment and Agricultural Production in the Centre of Research and Environmental Studies at the School of Humanities, National University of the Centre of the province of Buenos Aires. She is the senior author of more than 80 publications in peer review journals and scientific magazines, 11 book chapters published, one book about agroclimatic zoning for energy crops and more of 120 articles published in Proceedings of Congress and Conferences. She is an invited reviewer of more 30 reputed journals. Msc. Falasca is the principal investigator of Argentina on nontraditional energy crops. Her primary interests include: Agriculture, Non-traditional energy crops, Halophytes species, Green Energy, Ecology, Environmental management, Land use, Soils, Phys Physical geography, Climatology, Agro-ecological zoning, GIS. Author contact data: sfalasca@conicet.gov.ar; slfalasca@gmail.com; Author Scopus ID: 35755494700. Orcid: orcid.org/0000-0001-9359-7405.

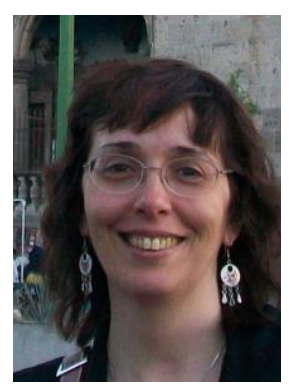

Sandra Pitta-Alvarez holds an undergraduate degree in pharmacy (1983) and a Master degree in the biochemical and pharmaceutical industries (1992). In 1998, she received her PhD degree in plant biotechnology from the University of Buenos Aires (UBA). Dr Pitta-Alvarez is a Researcher in the National Council for Scientific and Technological Research (CONICET), and she works at the Department of Biodiversity and Experimental Biology, UBA, Argentina. Previously, she worked at INTA. Some of her research interests include the biotechnological exploitation of microalgae for the production of food, pharmaceuticals, nutraceuticals and biofuels; the expression of heterologous proteins in eukaryotic systems and plant tissue culture and genetic engineering for the production of industrial products. Author contact data: sandrapitta-alvarez@conicet.gov.ar; spitta1959@gmail.com.

Orcid: orcid.org/0000--0003-1562-9779.

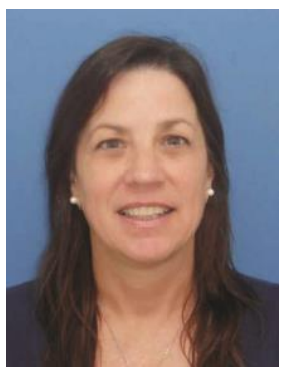

Ana Ulberich. She received the Cartographer degree in 1984 and the M.S. degree in Environmental Management of Urban Development in 1998 from the Universidad Nacional de Mar del Plata, Argentina. She is a professor of Cartography and Teledetection related subjects from the Environmental Science Department, at the School of Humanities of the Universidad del Centro de la Provincia de Buenos Aires (UNICEN), Argentina. She is a researcher in the fields of cartography, education and environment at the Centre of Research and Environmental Studies from the School of Humanities of the UNICEN. Author contact data: ulberich@fch.unicen.edu.ar, anaulberich@gmail.com.

Orcid: orcid.org/0000-0003-0098-1905. 